\title{
Loss of Books and Library Ownership Marks
}

$\mathrm{T}$ HE MECHANICAL processing of books is a topic to which little attention has been paid in the formal literature of librarianship. By "mechanical processing" is meant accessioning, affixing of bookplates, book pockets, and date due slips, ink stamping, embossing or perforating the library name, inserting secret identifying marks on designated pages, and labeling.

While the absence of this topic from library literature possibly indicates that the matter is not thought to be of sufficient importance to warrant public discussion, of the issues involved would be of value. Tauber has noted

The use of ownership marks is controversial, not because any library believes that they can be abandoned, but rather because there is no universal agreement as to what ownership marks are effective or how they are to be applied. There is considerable evidence in some library collections to support Adam's contention that librarians are enemies of books, and many cases of book mutilation have resulted from overzealous efforts by librarians to indicate ownership permanently. Edge-stamping, rubber stamp markings within the book, perforations, embossing, and bookplates have all been used. Stamping and perforating are the techniques to which most objection has been raised, particularly since these do most to disfigure the text or its illustrations. In almost any library examples can be found of handsome plates that have been disfigured by perforations or rubber stamps. Since there is no evidence to show that such ownership marks contribute materially to any reduction in losses through theft, modern library practice tends to limit the use of ownership marking considerably. Almost all that can be said at present concerning standard practice is that

$D r$. Stevens is assistant director of libraries, technical services, Ohio State University. most libraries do agree on the use of bookplates affixed to the inside of the front cover. ${ }^{1}$

In order to assemble data concerning the practices at large universities and research libraries, a questionnaire was mailed to the heads of technical services at 19 libraries, each containing approximately one million volumes and spending more than $\$ 175,000$ for books, periodicals, and binding. This constituted the group called together at the ALA midwinter meeting of 1956 by Robert $\mathrm{H}$. Muller for informal discussion of mutual problems. Primarily, the questionnaire was concerned with use of library ownership marks in bound and unbound material, microfilm, microcards and microprint. Two of the 19 libraries regularly use a rubber stamp on the inside of the front cover, reserving the bookplate for gifts, books purchased on endowed funds, and other exceptional volumes. The other 17 libraries regularly use a bookplate on the inside cover of bound books. Exceptions are made by some of these for rare books, pamphlets, and books which are bound or rebound for the library. The rubber stamp is commonly used in pamphlets in lieu of a bookplate. Some libraries use an end paper bearing the library seal in books which they bind or rebind, omitting the bookplate. Six libraries either emboss or perforate each book, usually on the title page, in addition to inserting a plate. Two others use the rubber stamp on the verso of the title page, and one stamps the book edge if sufficiently thick.

For the identification of microfilm, only six of the libraries mark the leader with the library's initials and call number, one simply by clipping a paper label to the

1 Maurice F. Tauber, Technical Services in Libraries (New York: Columbia University Press, 1954), p. 243-44. 
film. Thirteen libraries mark only the box containing the microfilm. The library name is usually part of the target when microfilming is done locally. Eight libraries put no ownership stamp on either microcards or microprint. Nine stamp the verso of microcards, but apparently do not stamp the verso of microprint cards. Two of these are considering stamping the verso of microprint cards also. Two libraries report that the problem of stamping microcards and microprint is under consideration, but that they have not yet reached a conclusion.

The use of library ownership marks is associated with the problem of loss of books. Loss may be attributed to two general causes. On the one hand, there is loss due to accident, misplacing, and carelessness. On the other hand, some loss must be attributed to intentional theft, although the thief of ten considers that he is merely borrowing without going through the usual procedure, and intends to return the item when his need has been satisfied. Several factors seem to be involved in library theft, such as the rarity and consequent attractiveenss of a book or manuscript, the degree to which it may be borrowed within library regulations, the ease with which another copy may be acquired, and conversely the difficulty, danger, and possible punishment risked in stealing it. Before the invention of printing, and up to the development of mass publishing methods, books were considerably more rare and of greater value than are most modern books. Hence, the temptation to hide even bulky volumes under his cloak, in the attempt to remove them surreptitiously from the library, was sometimes too much for the cleric or lay scholar. In medieval libraries loss of books from theft was not uncommon, and some measure of protection was found in the insertion in the book itself of a curse against any potential thief. ${ }^{2}$

${ }^{2}$ Lawrence S. Thompson, "Notes on Bibliokleptomania," Bulletin of the New York Public Library, XLVIII (1944), 731. Cf, also Thompson, "A Cursory Survey of Maledictions," Bulletin of the New York Public Library, LVI (1952), 55-75.
Books were also chained to fixed furniture in order to reduce loss.

In modern times, with the mass production of books and with the modern relaxation of library lending regulations, the temptation to remove books illegally from the library no longer exists to the same extent as formerly. The chain and curse have given way to the bookplate, rubber stamp, embossed seal, and other marks, for the protection of books against theft and loss. A number of ways in which these devices can be effective may be listed: (1) To facilitate the checking of books by a guard stationed within the library door, if this checking system is adopted by the library; (2) To deter readers from taking books past the library guard without following the proper loan procedure; (3) To assist the home reader in distinguishing library books from his own; (4) To remind the absent-minded borrower to return books to the library; (5) To aid in the recovery of stolen books through the use of identifying marks to prove ownership; and (6) To aid in the return of lost books by the identification of the owner to the finder.

Let us assume that some type of library ownership mark is necessary and desirable. The intemperate use of multiple ownership marks requires extra time in the processing operations, adds to the risk of mutilation through applying the marks, and makes psychological implications to the honest borrower that the library is overly fearful of losing its books and that the library is indirectly imputing base motives to every potential borrower. The problem is, therefore, to avoid the use of multiple identifying marks unnecessarily.

The different identifying marks in current use for bound and unbound volumes fall into four general types. These, together with a brief examination of the usefulness of each, are as follows:

1. Bookplate or ink stamp on or near the inside of the front cover. On books bound or rebound by the library, an 
identifying end paper might be used in lieu of a bookplate. Any one of these marks will adequately serve each of the five purposes of the ownership mark listed above, provided that it remains intact. If carefully and tastefully inserted, the bookplate and special end paper also have the advantage of enhancing the beauty of the book, rather than mutilating it.

2. Call number. While not generally considered a mark of ownership, the call number, inscribed or stamped on the lower part of the spine of the book, is frequently used as a quick means of identifying library copies of books. It will usually serve any of the first three purposes listed above. The library imprint, stamped on the spine of books bound or rebound by the library, serves the same purposes.

3. Embossed seal or perforated initials on the title page. When used, this mark is usually affixed in addition to a bookplate. The only advantage these marks have over the bookplate and other marks in Group $\mathrm{l}$ is that they are more difficult to remove. However, any book thief worth his salt can easily remove an embossed seal so as to escape normal detection. ${ }^{3}$ Certainly there is no need to use the perforated or embossed mark in addition to the bookplate. If the added protection of the perforated mark is wanted, then the bookplate may well be omitted.

4. Some hidden or secret mark on one or more coded pages. This is intended to be unobserved by the borrower, and hence also to the finder if the book is lost, but serves as an identifying mark by which the library could prove its ownership. These code marks probably serve no useful function, except that of enabling the library to furnish proof of its ownership in legal action. Conceivably they could also help the library guards in checking on the removal of library books, except that the secret location of these

\footnotetext{
3 Thomas M. Johnson, "Catching the Book Crooks,"
} Saturday Review, July 24, 1954, p. 6-7+. marks will soon be known to most borrowers when these locations are repeatedly checked by guards. If the location is indeed hidden to all but the initiated on the library staff, then such marks cannot aid in any of the loss prevention functions listed above, except proof of ownership.

The identifying marks examined in the preceding paragraphs are used on bound and unbound materials. For special materials such as microfilms, microcards, and microprint, the use of ownership marks is necessarily restricted. Microfilms can be marked on the leader by electric stylus or perforation. Microcards or microprint must be rubber stamped on the verso of each card, always with the possible consequence of having the ink smear on the face of an adjacent card. Usually they are housed in a restricted location, or under close supervision, and either do not circulate or are lent only to libraries. Since they can be used only with a special reading machine, they are not subject to the same opportunities for loss as are printed books.

The conclusion of this brief examination of the use of library ownership marks is that the bookplate alone will serve all functions for which ownership marks are devised. The call number, which will be used for other purposes, will also aid in identification. The bookplate, or end papers bearing the library seal, when carefully used, can add to the attractiveness of a book rather than mutilating it. The only instance in which it is insufficient to prevent loss of books is in theft, when the thief covers up his crime by easily removing the plate. But the object of theft is usually the rare book or manuscript, to which the alternative marks by embossing, perforating, or rubber stamping are rarely applied. Furthermore, with the exception of a perforated mark, these can also be removed by the thief with little more difficulty. The obvious means of protection for rare books and manuscripts lie in careful housing and super- 
vision, rather than in so marking the volume that it can be identified after theft. ${ }^{4}$

In the separate housing of rare books under close supervision, and in the restricted loan regulations applying to them, they may be considered in a special class, like microfilm, microcards, and microprint. Unless unusual loan practices or other conditions warrant the use of an ownership mark, it would seem unnecessary to mark these materials. Depending on the local loan regulations and other conditions, phonorecords, scores, maps, plates, and other unbound materials might also best be left unmarked. The two criteria to be applied in regard to

\footnotetext{
4 The Library of Congress has recently decided (Information Bulletin, XV (1956), 243-44) to stamp its manuscripts "with a small Library of Congress seal imprinted in a pale red ink." This decision was the consequence of a theft of certain valuable manuscripts, which were recovered after a bookdealer in Philadelphia had reported the offer of some manuscripts under unusual circumstances. Another measure following the theft was the addition of a guard in the Manuscript Reading Room, besides the guards regularly stationed at the library exits. The decision to stamp all manu scripts was made only after a careful study of avail able inks, in order to find one that would be both permanent and transparent. The use of the ink stamp seems to me to be an extreme measure, and one of doubtful efficacy. The recently stolen manuscripts were recovered even though they were not stamped. It would be an unimaginative thief, or at least an unambitious one who could not remove any ink stamp which did not who could not reme documents would seem to be the careful issuing and checking of documents before and after each use.
}

each of these special classes of material lie in two questions: Does an ownership mark serve in any way to reduce possible loss of the material? Is the time involved in applying marks of ownership, and other disadvantages, in any way commensurate with the amount by which loss may be reduced? Unless the material is available for use outside the library, or is of sufficient value to encourage theft, the application of ownership marks probably cannot be justified.

The elimination of unnecessary ownership marks is undertaken as much in the interest of economy of operation as in the protection of books from mutilation. A program based on numerous rules and requiring a separate decision for the processing of each volume would defeat its own purpose. The program should be streamlined in its operation as well as in its use of different marks of ownership. A normal routine of processing books and serials should be adopted, involving the fewest rules consistent with adequate protection. Exceptions to this routine should be held to a minimum, and these should be readily identifiable by those engaged in the processing operations.

\section{Council on Library Resources, Inc.}

(Continued from page 473)

systems, modern developments in printing and duplication, mechanical translation, and various devices for mechanizing the processes of information storage and retrieval-might produce very rewarding results for both libraries and their users.

\section{Importance of Libraries}

Libraries constitute in a very real sense the communal memory of mankind. They are charged with maintaining the organized record of human experience. Having access to this record, mankind can progress; lacking it, each generation would be condemned to end- less repetition of the experiments of its ancestors.

This is true even for the laboratory sciences. Although the individual laboratory scientist may not himself make much use of the great libraries, yet the critical tables, the compendia, the abstracting services and the literature surveys which make his laboratory research profitable have all been made possible by libraries. Meanwhile, for the nonlaboratory sciences-history, law, and the other humanities and social sciences-the library serves to a large extent as the "laboratory," where books replace test-tubes and formaldehyded frogs. 